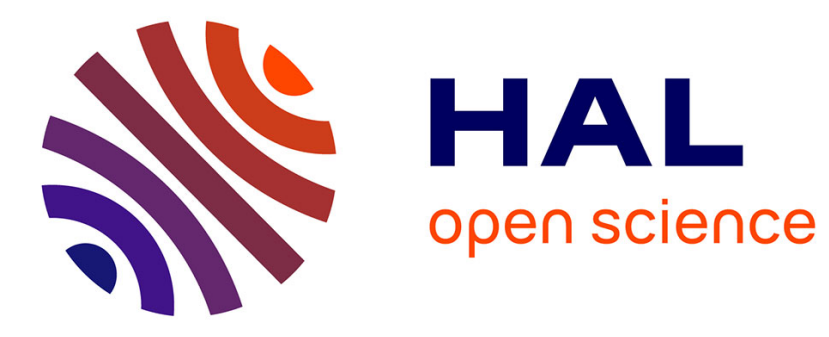

\title{
New Barium Volatile Complexes Useful in CVD
}

\author{
A. Drozdov, S. Troyanov, A. Pisarevsky, Y. Struchkov
}

\section{To cite this version:}

A. Drozdov, S. Troyanov, A. Pisarevsky, Y. Struchkov. New Barium Volatile Complexes Useful in CVD. Journal de Physique IV Proceedings, 1995, 05 (C5), pp.C5-503-C5-508. 10.1051/jphyscol:1995558 . jpa-00253920

\section{HAL Id: jpa-00253920 https://hal.science/jpa-00253920}

Submitted on 1 Jan 1995

HAL is a multi-disciplinary open access archive for the deposit and dissemination of scientific research documents, whether they are published or not. The documents may come from teaching and research institutions in France or abroad, or from public or private research centers.
L'archive ouverte pluridisciplinaire HAL, est destinée au dépôt et à la diffusion de documents scientifiques de niveau recherche, publiés ou non, émanant des établissements d'enseignement et de recherche français ou étrangers, des laboratoires publics ou privés. 


\title{
New Barium Volatile Complexes Useful in CVD
}

\author{
A. Drozdov, S. Troyanov, A. Pisarevsky* and Y. Struchkov* \\ Moscow State University, Department of Chemistry, 119899 Moscow, Lenin Hills, Russia \\ * Nesmeyanov Institute of Organoelement Compounds, 28 Vavilov Str., 117813 Moscow, Russia
}

\begin{abstract}
New volatile barium precursors based on pivaloyltrifluoroacetone are obtained and studied. The results of $\mathrm{X}$-ray structure determination of two compounds are given.
\end{abstract}

\section{INTRODUCTION}

The major problem with the MOCVD of superconducting thin films is the low thermal stability and unsufficient volatility of barium chelates used. Among them barium 2,2,6,6-tetramethylheptanedionate-3,5 $\mathrm{Ba}(\mathrm{thd})_{2}$ and $1,1,1,5,5,5$-hexafluoropentanedionate-2, 4 $\mathrm{Ba}(\mathrm{hfa})_{2}$ are the main ones. These compounds possess quite different structure and properties. Thus, the former is a tetranuclear complex [1-4], one of its hydrates consists of a dimeric fragments combined into hexanuclear species [5], while the latter (in form of hydrate [6], or ether solvate [7]) has a chain structure. Due to its molecular structure $\mathrm{Ba}_{4}$ (thd) $_{8}$ can be quantitatively sublimed at temperature range $220-240^{\circ} \mathrm{C}$, whereas the volatility of polymeric $\left[\mathrm{Ba}(\mathrm{hfa})_{2}\right]_{\mathrm{n}}$ is by far less. Nevertheless, mononuclear mixed ligand diketonates with hfa-ligand are much more volatile than those with thd. We decided to study barium complexes with 1,1,1-trifluoro5,5-dimethylhexanedione-2,4 (pivaloyltrifluoroacetone, Hpta), which contains both tert-butyl (as in Hthd) and trifluoro-methyl (as in Hhfa) terminal groups. We succeeded to obtain sublimed product and also its water, tetraglyme and 2,2'-dipyridyl (dipy) derivatives.

\section{EXPERIMENTAL}

2. 1 General proceedings

IR spectra were recorded on a Perkin-Elmer PEFTIER spectrometer as 
Nujol mulls. Thermogravimetric analysis was performed by using Paulik-Paulik thermogravimetric system under a dry nitrogen flow; the furnace was heated at $5^{\circ} \mathrm{C} \min ^{-1}$ from ambient temperature up to $500^{\circ} \mathrm{C}$. The $\mathrm{X}$-ray powder patterns were obtained with a DRON-2 powder diffractometer (Co $\mathrm{K}_{\alpha}$-radiation).

\subsection{Synthesis}

$\mathrm{Ba}_{2}(\mathrm{pta})_{4}\left(\mathrm{H}_{2} \mathrm{O}\right)_{2}$ (I). $4.09 \mathrm{~g}$ of Hpta was added with stirring to 100 $\mathrm{ml}$ of saturated $\left(15^{\circ} \mathrm{C}\right)$ freshly prepared solution of recrystallized $\mathrm{Ba}(\mathrm{OH})_{2} \cdot 8 \mathrm{H}_{2} \mathrm{O}$. The white precipitate formed was extracted by ether. Extract was evaporated for dryness. The substance was recrystallized from water ethanol. Complex is a white solid substance, soluble in ether, benzene and ethanol. IR $\left(\mathrm{cm}^{-1}\right): 3400,1630,1520,2880-2980$, $1260,1250-1360,525,400$.

$\mathrm{Ba}_{4}$ (pta) 8 (II) was obtained by heating $\mathrm{Ba}_{2}$ (pta) ${ }_{4}\left(\mathrm{H}_{2} \mathrm{O}\right)_{2}$ in vacuo 0.01 torr at $200-220^{\circ} \mathrm{C}$. It is a white powder, air sensitive. It dissolves in ether and benzene. IR $\left(\mathrm{cm}^{-1}\right):$ 2880-2980, 1635, 1590, 1520, 1260, 1180, 1120, 565, 520, 480.

The adduct with overall composition $\mathrm{Ba}(\mathrm{pta})_{2}$ (dipy) $_{1.5}$ (III) was prepared dissolving $\mathrm{Ba}$ in benzene solution of Hpta and dipy $(\mathrm{Ba}:$ Hpta:dipy $=1: 2: 2)$. The white precipitate formed was recrystallized from toluene. IR $\left(\mathrm{cm}^{-1}\right): 1625,1590,1560,1540$, $1455,1180,1120,765,595,520,480$.

$\mathrm{Ba}$ (pta) 2 (tetraglyme) (IV) [8] was synthesized as a previous compound using tetraglyme instead of dipy (Ba:Hpta:tetraglyme = $1: 2: 1$ ) in a mixture of pentane and ethylacetate. A white solid substance unsoluble in pentane, soluble in ether. IR $\left(\mathrm{cm}^{-1}\right):$ 1510, 1620,1640 .

\subsection{Crystal structure determination}

Diffraction data were collected on Siemens P3/PC diffractometer using Mo-k $\mathrm{K}_{\alpha}$ radiation with a graphite monochromator. Crystals were placed in glass capillaries for the measurements of intensities. To record the intensities of reflections $\theta-2 \theta$ scan method was used. The calculations were performed using the SHELXTL PLUS program package [9]. The positions of barium atoms were found by direct methods. Successive difference Fouriex syntheses gave the coordinates of other non-hydrogen atoms. Structures were anisotropically refined by full-matrix least-squares for all non-hydrogen atoms to $R=0.054$ (structure I) and 0.056 (structure II). 
Crystal data for I: $\mathrm{BaC}_{16} \mathrm{H}_{20} \mathrm{~F}_{6} \mathrm{O}_{4}, \mathrm{P} \overline{\mathrm{i}}, \mathrm{a}=14.382(7), \mathrm{b}=15.777(8)$, $c=20.613(9) \AA, \alpha=95.21(2), \beta=108.03(2), \gamma=96.25(2)^{\circ} ; V=4383 \AA^{3}, z=8$.

Crystal data for II: $\mathrm{BaC}_{16} \mathrm{H}_{22} \mathrm{~F}_{6} \mathrm{O}_{5}, \mathrm{P} \overline{1}, \mathrm{a}=8.641(3), \mathrm{b}=15.737(4)$, $C=16.372(5) \AA, \alpha=79.43(2), \quad \beta=82.21(2), \gamma=82.34(2)^{\circ} ; V=2155 \AA^{3}, \quad z=4$.

\section{RESULTS AND DISCUSSION}

According to $X$-ray structural study of sublimed Ba(pta) $2^{\prime}$ it consists of tetranuclear units $\mathrm{Ba}_{4}$ (pta) $8, \mathrm{Ba}$ atoms form rhombus (Fig.1). In the cell there are two types of crystallographically independent $\mathrm{Ba}_{4}$ (pta) 8 molecules with similar interatomic distances and coordination modes. Ba...Ba distances in each tetranuclear species are : $4.184 \AA$ (4.199 $\AA$ in the other tetramer) for $\mathrm{Ba}(1) \mathrm{Ba}(2)$ and $4.073 \AA(4.078 \AA)$ for $\mathrm{Ba}(1) \mathrm{Ba}\left(2^{\prime}\right)$. In this compound there are weak contacts between fluorine atoms of $\mathrm{CF}_{3}$-groups and metal ion (Ba...F 2.87 - 3.29 ). Similar interactions have been also found in barium chelates with hfa $[6,7]$. Due to coordination of the fluorine atoms, coordination modes of ligands differ from those found in $\mathrm{Ba}_{4}$ (thd) 8 (see Fig. 1 in the paper of A.Drosdov and $S . T r o y a n o v$ in the Conference Procedings). Each Ba atom has $\mathrm{CN}=9 \quad 170$ +2 F), Ba-O distances ranging from 2.59 to $2.92 \AA$. The ligands

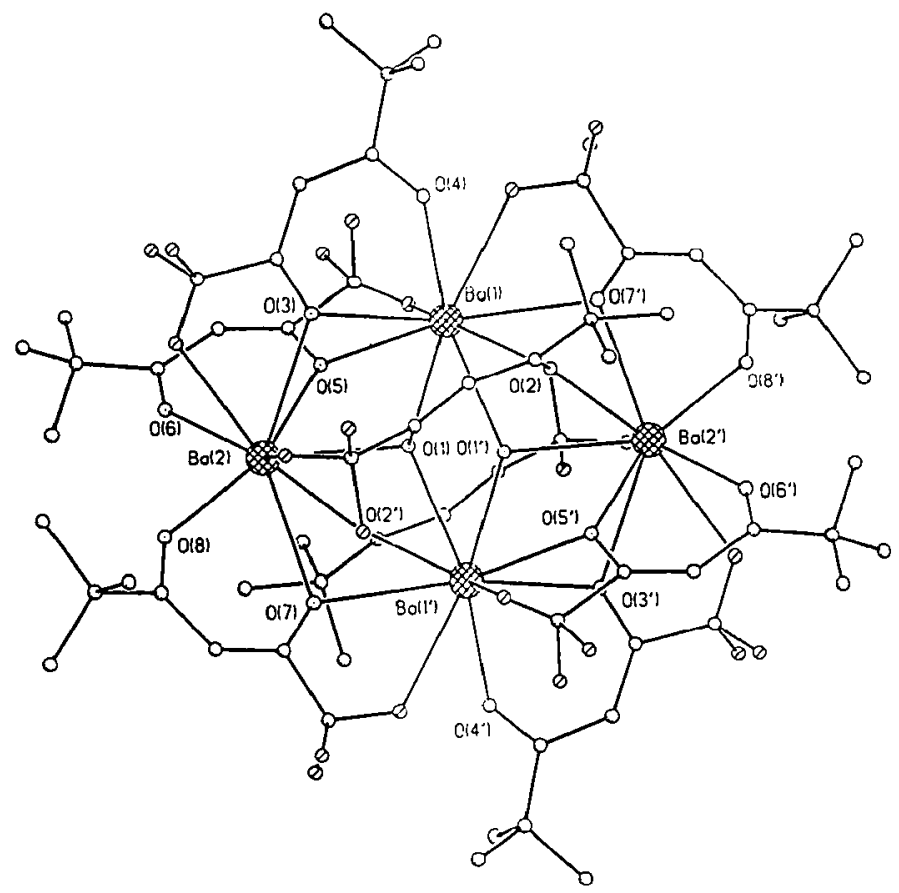

Figure 1. Tetranuclear $\mathrm{Ba}_{4}{ }^{(p t a)}{ }_{8}$ molecule. 
$O(3) O(4), O(5) O(6), O(7) O(8)$ in both tetranuclear molecules belong to chelating bridging coordination mode (signed $1 \mathrm{~b}$ in [2]). The Ba... distances in chelate rings (ranging from 2.60 to $2.78 \AA$ ) are shorter than bridging ones (Ba-O 2.79-2.82 ). The Iigand $O(1) O(2)$ in both tetramers unites all the four barium atoms in a tetranuclear molecule. $O(1)$ atom is three-dentate being connected with $\mathrm{Ba}(1)$, $\mathrm{Ba}\left(1^{\prime}\right)$ and $\mathrm{Ba}(2)$ atoms. $\mathrm{O}(2)$ is coordinated by $\mathrm{Ba}(1)$ and $\mathrm{Ba}\left(2^{\prime}\right)$ atoms. We don't know any other example of such coordination mode in metal diketonates. It includes one chelate ring with $\mathrm{Ba}(1)$ and three bridging $\mathrm{Ba}-\mathrm{O}$ bonds. The different coordination number of $O(1)$ and $O(2)$ results in a strong distortion of the chelate ring (the difference of two Ba-O bond distances in the first tetramer is 0.15 $\AA$, and $0.19 \AA$ in the second). The average $O(1)-B a$ distance in both tetramers is $2.86 \AA$, while $O(2)-\mathrm{Ba}$ is $2.74 \AA$ in the first tetramer and $2.72 \AA$ in the second. The larger is the coordination number of the oxygen, the larger Ba-O distance is.

The structure of $\mathrm{Ba}(\mathrm{pta})_{2}\left(\mathrm{H}_{2} \mathrm{O}\right)$ (Fig.2) consists of infinite chains: Ba atoms are linked by chelating bridging pta-ligands and $\mu-\mathrm{H}_{2} \mathrm{O}$ molecules. Distances $\mathrm{Ba} . \mathrm{Ba}(4.345 \AA)$ are slightly longer

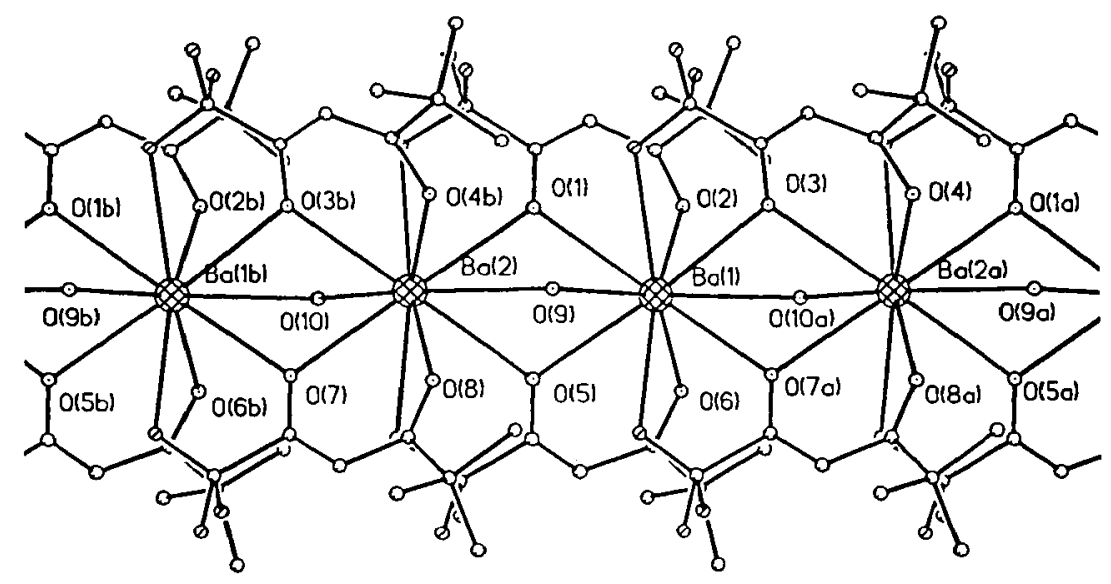

Figure 2. Chain structure of $\left[\mathrm{Ba}(\mathrm{pta})_{2}\left(\mathrm{H}_{2} \mathrm{O}\right)\right.$ 
than in $\mathrm{Ba}_{2}$ (hfa) $4\left(\mathrm{Et}_{2} \mathrm{O}\right)$ [7] (4.213 $\AA$ and $4.229 \AA$ ) due to bulky tert-Bu groups. Each of two Ba atoms have $\mathrm{CN}=10(80+2 \mathrm{~F} ; \mathrm{Ba}-\mathrm{O}$ (pta) $\left.2.69-2.88 \AA, \mathrm{Ba}-\mathrm{O}\left(\mathrm{H}_{2} \mathrm{O}\right) 2.77-3.10 \AA, \mathrm{Ba} \ldots \mathrm{F} 2.97-3.03 \AA\right)$ All the pta ligands in the structure are chelate bridging (one chelate ring and one bridging $\mathrm{O}$-atom). The Ba-O distances in chelate ring are in range $2.69-2.78 \AA$, whereas the bridging ones are longer 2.86-2.88 $\AA$. This structure is very similar to $\mathrm{Ba}(\mathrm{hfa})_{2}\left(\mathrm{H}_{2} \mathrm{O}\right)$ studied by Bradley et al [6], in which $\mathrm{Ba}$ is also ten-coordinated.

Complex Ba(pta) ${ }_{2}$ (tetraglyme) [8] was found to be mononuclear with the structure very similar to other tetraglyme adducts known $(\mathrm{CN} \mathrm{Ba}=9)[10,11]$. In the molecule of adducts there are no Ba..F contacts (see Fig.5 in the the paper of A. Drozdov and S. Troyanov).

Being heated under nitrogen flow $\mathrm{Ba}(\mathrm{pta})_{2}\left(\mathrm{H}_{2} \mathrm{O}\right)$ first looses water $\left(80-90^{\circ} \mathrm{C}\right)$ and then decomposes and partly sublimes $\left(160-220^{\circ} \mathrm{C}\right)$. In vacuo 0.01 torr this compound looses water $\left(40-50^{\circ} \mathrm{C}\right)$ and then sublimes in the form of $\mathrm{Ba}_{4}(\mathrm{pta})_{8}$. The latter compound can be resublimed in vacuo at $180-200^{\circ} \mathrm{C}$, that is slightly lower in comparison with those for $\mathrm{Ba}_{4}$ (thd) 8 . Being heated in inert atmosphere $\mathrm{Ba}(\mathrm{pta})_{2}$. (dipy) 1.5 evolves dipy $\left(250^{\circ} \mathrm{C}\right)$ and then $\mathrm{Ba}_{4}$ (pta) 8 remained decomposes with partial sublimation $\left(300^{\circ} \mathrm{C}\right)$. The residue is barium fluoride. Being heated in vacuo 0.01 torr adduct with dipy first looses the additional ligand $\left(120-140^{\circ} \mathrm{C}\right)$; remaining $\mathrm{Ba}$ (pta) 2 can be sublimed at $180-200^{\circ} \mathrm{C}$ as $\mathrm{Ba}_{4}$ (thd) 8 . Under vacuo 0.01 torr at $150^{\circ} \mathrm{C}$ in the case of $\mathrm{Ba}$ (pta) ${ }_{2}$ (tetraglyme), both thermal decomposition to dipy and $\mathrm{Ba}_{4}$ (pta) 8 and sublimation of adduct take place. $\mathrm{Ba}_{4}(\mathrm{pta})_{8}$ remained can be sublimed at $220^{\circ} \mathrm{C}$.

The complexes with pta mentioned are suggested as precursors for MO CVD process of thin films production. In comparison with water barium thd-chelates (usually a mixture of different unstable products formes during storage) in $\mathrm{H}_{2} \mathrm{O}-\mathrm{Ba}(\mathrm{pta})_{2}$ system only one stable compound is formed - monohydrate. This substance was kept for 6 months in a closed vessel without any changes and without decrease of volatility. The use of $\mathrm{Ba}_{4}$ (pta) 8 instead of $\mathrm{Ba}_{4}$ (thd) 8 allows to diminish the sublimation temperature for $10^{\circ} \mathrm{C}$. Adduct with dipy is the best form to store a precursor for a long time.

\section{REFERENCES}

[1] Gleizes A., Sans-Lenain S., Medus D. Compt. Rend. Sci. Paris, serie II 313 (1991) $761-766$. 
[2] Drozdov A.A., Troyanov S.I. Polyhedron 11 (1992) 2877-2882.

[3] Drake S.R., Hursthouse M.B., Malik K.M.A., Otway D.J. J. Chem. Soc. Dalton Trans. (1993) 2883-2890.

[4] Gleizes A., Drozdov A., Troyanov S. Koord. Khim. 20 (1994) $922-927$.

[5] Drozdov A., Troyanov S., Pisarevsky A., Struchkov Yu. Polyhedron 13 (1994) 2459-2461.

[6] Bradley D., Hasan M., Hursthouse M., Motevalli M., Khan O., Pritchard R., Williams J. Chem. Commun. (1992) 575-576.

[7] Drozdov A., Troyanov S. Chem. Commun. (1993) 1619-1621.

[8] Kuzmina N., Drozdov A., Zotova T., Kupriyanova G., Pisarevsky A., Struchkov Yu. Koord. Khim. 20 (1994) 743-746.

[9] Robinson W., Sheldrick G., Crystallographic Computing Techniques and New Technologies, Eds. N. Isaacs and M. Taylor (University Press, Oxford, 1988) 366.

[10] Gardiner R., Brown W., Kirlin P., Rheingold A. Chem. Mater. 3 (1991) 1053-1059.

[11] Drozdov A., Troyanov S. Koord. Khim. 20 (1994) 171-174. 